\title{
Justice through Virtuous Leadership and Decision- making. The Witness that was Mary-Anne Elizabeth Plaatjies-Van Huffel
}

\author{
Nico N. Koopman \\ https://orcid.org/0000-0002-7022-7847 \\ Stellenbosch University \\ nkoopman@sun.ac.za
}

Let your smile change the world; but don't let the world change your smile (Connor Joel Franta)

\begin{abstract}
This essay honours Mary-Anne Elizabeth Plaatjies-Van Huffel. It focuses on her role as a leader and decision-maker. The essay discusses the notion of virtuous decision-making. A brief description is offered of the notion of virtue. Thereafter, the seven virtues, faith, hope, love, wisdom, moderation, fortitude and justice are discussed. Justice is portrayed as the Summum Bonum, the supreme good and ultimate goal. In seeking justice in church and in the world, Plaatjies-Van Huffel was nurtured by the contents of her faith, the Triune God and those who belong to God; by realistic, resilient and responsive hope; by the excellence of love; by wisdom, sensitive intuition, sound judgement, careful discernment; by moderation and temperance; and by the fortitude and courage to make an unfamous decision and to implement it. In her person and example as a pastor, academic and leader, Plaatjies-Van Huffel verifies the notion of virtuous leadership and decision-making.
\end{abstract}

Keywords: Mary-Anne Elizabeth Plaatjies-Van Huffel; virtues; leadership; justice; decision-maker

\section{UNISA $\cong$}




\section{Introduction}

This essay honours Mary-Anne Elizabeth Plaatjies-Van Huffel. It focuses on her role as a leader and decision-maker. The essay discusses the notion of virtuous decisionmaking. A brief description is offered of the notion of virtue. Thereafter, the seven virtues are discussed. In a final round, Plaatjies's embodiment of those virtues as a decisive leader is discussed. Virtues culminate in a life of justice for all. The leadership of Plaatjies-Van Huffel and her decision-making sought justice for all. Through the practice of virtue, she sought to advance justice in home, church, academy and the broader society.

This application to Plaatjies-Van Huffel's life draws upon my close walk with her, since childhood and youth. She was born and raised in Prieska and Niekerkshoop, close to Prieska. We come from the same extended family and shared in each other's lives over many decades. We later became colleagues in church life and in academic life. We served together in various church, university and civil society committees. This essay draws upon, extends, improvises and applies my work over decades in the field of virtue ethics. ${ }^{1}$

In a Festschrift, some contributions offer an analysis of the publications of the one honoured. Some contributions are written by peers in the same discipline as the one honoured. Some contributions are simply submitted as independent works dedicated to the one honoured, without explicit reference to the one celebrated. Some contributions are written from other disciplines. This contribution is written from the field of Systematic Theology and Ethics, specifically from the field of virtue ethics. It does not engage with the literature of Plaatjies-Van Huffel. It is written by a colleague and friend since childhood, who discovered that what constitutes such a major feature of his own research, found embodiment in the life of the one honoured. This essay, therefore, discusses the individual and interdependent virtues, and demonstrates briefly how the leadership and decision-making of Plaatjies-Van Huffel — who was both theologian and ecumenical leader and decision-maker - reflect these virtues. By identifying PlaatjiesVan Huffel as a leader and decision-maker of virtue, this essay affirms the worth of virtue for leadership and decision-making. The leadership and decision-making of Plaatjies-Van Huffel demonstrate that the notion of virtuous leadership and decisionmaking, for which churches, communities, countries and continents hunger, is not a pipedream. By verifying virtue with her example, we honour Plaatjies-Van Huffel.

1 Two prominent essays that I draw extensively from, are Koopman (2005 and 2012). 


\section{Virtue}

This essay does not discuss virtue theory as a specific approach within ethics, in relation to approaches like deontology, teleology and utilitarianism. It focuses on the seven interdependent theological virtues.

US ethicist, J. Philip Wogaman $(1989,29)$, offers a valuable description of virtue. He describes virtue as "a disposition of the will towards a good end, as a tendency to think or behave in accordance with goodness, as a habit of the will to overcome a threat to our ultimate good." Based on this very brief, and highly helpful definition, we can postulate that a virtue is part of the habitus, habits with which we live. It refers to things that we do intuitively, almost in a programmed manner, almost without prior reflection. A virtue is simply the habit to offer my seat in the bus to an elderly person, without even reflecting upon it. The good deed of offering my seat, flows from my virtue, my excellency, my divine power (arète in Greek), my programmedness, inclination, tendency, predisposition, to be good and to act in accordance with goodness. Good deeds flow from virtues, and good values find embodiment and incarnation in virtues. Virtue is acquired in a process of consistent and collective habitual behaviour.

US theologian, David Cunningham (1998), identifies so-called Trinitarian virtues and Trinitarian practices that enable us to oppose our craving for violence, our neglect of children and our misguided quest for homogeneity. The three Trinitarian virtues are polyphony, participation and particularity. The three Trinitarian practices are peacemaking, pluralising and persuading. These Trinitarian virtues and practices can help us to deal with peaceable and just living in pluralistic societies, especially when we are faced with incommensurable positions and lack of consensus.

Under the influence of Mikhail Bakhtin, Cunningham (1998, 156, 164) describes polyphony as a plurality of independent and unmerged voices and consciousnesses, with equal rights and each with its own world. These voices are combined, but not merged. This polyphonic unity is informed and underwritten and - I would add, constituted - by the intra-trinitarian union within the triune God, and in the inter-trinitarian union between the triune God and God's people and creation.

For Cunningham (1998, 180-183) our participation in the triune God has its roots in the incarnation of Christ. For him, the Chalcedon formulation has universal significance. This classic formulation states that the divine and humane indwells each other without confusion, without change, without division, without separation. This perichoretic coexistence, koinonia, communion, mutual indwelling, mutual participation of the human and divine in Christ, facilitate and enable the participation of humans and nature in the triune God and each other.

The koinonia within God, and between God and his creation is, according to Cunningham (1998, 183-186), the communion into which human beings are called to live with each other. Koinonia and participation in each other's lives are seen in 
something as basic as eating together. In these common meals we are sensitive and cater for the dietary restrictions and the aesthetic and gustatory preferences of all. At mealtime we practise patience, sensitivity for all needs, careful listening, and observance and respect for a diversity of cultural dietary practices, eating habits and table manners.

The Trinitarian virtue of particularity, explains Cunningham (1998, 197-230), makes room for difference and individuality, and it resists isolation and separation. Particularity embraces diversity, contextualities, subjectivities, polyphony, participation. Particularity cannot live with a quest for homogeneity, uniformity and sameness that do away with the rich diversity and polyphony of a diversity of participants in the life together.

The virtues of polyphony, participation and particularity enable us to engage in practices of peace-making, pluralising and persuasion in pluralistic societies of violence, homogenisation and coercion. These virtues oppose the subjugation, elimination and the destruction of the otherness of the other in the quest for homogenisation and cooption and forced conformation. These virtues advance hospitality and ownership through multiple, honest and accessible modes of discourse and practice. These virtues advance the practice of persuading and an understanding of authority and power that do not reflect coercion, but rather the persuasive power of the triune God (Cunningham 1998, 234-235).

For Cunningham $(1998,123)$, virtues are dispositions that God has by nature, and in which we participate by grace. Virtues are characteristics of the triune God that are bestowed upon us freely.

More recently, Kenneth Barnes (2018, 22-23) also attributes the seven theological virtues to Thomas Aquinas. Thomas drew upon Greek philosophy as practised by, amongst others, Aristotle and the Stoics. Thomas also borrowed from early church fathers and mothers like Gregory the Great and Augustine of Hippo. Aristotle has identified four so-called cardinal virtues. Cardinal is derived from the Latin word cardo, which refers to the hinge of a door. The four cardinal virtues are, therefore, the hinge on which all virtues turn. These virtues are justice, moderation/self-control, discernment/wisdom, and courage/fortitude. Thomas Aquinas added three theological virtues to these four, namely faith, hope and love.

According to Barnes $(2018,23)$, Thomas viewed virtues as simple, easily accessible and practicable. Barnes $(2018,13,23)$ also refers to the universal appeal of virtues. He explains that the virtues and Decalogue had been at the legal and ethical thinking in Western societies for centuries. The practical nature and the appeal of virtues outside the circles of Christian faith, prompted Barnes to do an assessment of current capitalism through the lens of the seven virtues. He employs the notion of common grace for the common good to articulate this universal appeal of the virtues, and of an envisaged virtuous capitalism. 
Societies hunger for people of public and civic virtue: public wisdom in contexts of complexity, ambiguity, tragedy and aporia (dead-end streets); public justice in context of inequalities and injustices on local and global levels; public temperance in context of greed and consumerism amidst poverty and alienation; public fortitude amidst situations of powerlessness and inertia; public faith amidst feelings of disorientation and rootlessness in contemporary societies; public hope amidst situations of despair and melancholy; public love in societies where public solidarity and compassion seem to be disappearing. ${ }^{2}$

The notions of virtue and character are related and interdependent. According to American theologians, Bruce Birch and Larry Rasmussen $(1989,124)$, an etymological study of the word "character" indicates that character has to do with the engraving of particular principles into a person. They refer to the Greek roots of the word, which means engraving tool, and by extension the marks made by an engraving tool. Character, hence, has the notion of values that are engraved into a person, over time, so that they become assimilated, incarnated, and embodied in the person. Character, like the virtues, therefore, develops over time in communion with God and other human beings.

Virtues inform decision-making. US theologian, James Childs (1992), discusses the importance of virtue for ethical decision-making in various walks of life. In several publications on decision-making, the significance and indispensability of the virtues are acknowledged and emphasised. English and New Zealand feminist philosopher, Rosalind Hursthouse (2000), provides a great systematic work on virtue ethics, and throughout her work explains how virtue ethics helps us to deal with the meta-ethical dimensions of the moral life, and, therefore, discussions about what is moral truth. It also helps us to better understand the role of desires and emotions in moral living. Virtues serve simultaneously as character traits, illuminators of moral dilemmas and guides for moral decisions and actions.

Leadership and decision-making are inseparable. In fact, positions of leadership call us to make decisions, to make choices, to formulate policies and to implement them. To be a leader, is to decide. This, of course, applies to all humans. In a certain sense we can say: we decide, therefore we are. Leaders, nevertheless, have less room to avoid the responsibility to choose, decide, and take a stance.

In the next parts of this essay, the seven virtues are discussed. Each time hints are provided about its meaning for leadership and decision-making. It will also become clear how the three virtues of Cunningham, polyphony, participation and particularity, function in symbiosis with the seven theological virtues, and how they offer ways in which the theological virtues can be practised in pluralistic societies. A discussion of

2 Koopman (2007) discusses this hunger of societies for civic and public virtue more extensively. 
this symbiosis would be highly interesting and important, but it falls outside the scope of this essay.

\section{Virtuous Leadership and Decision-making in Faith}

Thomas Aquinas added faith, hope and love to the four cardinal virtues that philosophers like Aristotle had formulated.

Drawing upon Augustine, the Faith and Order document, Confessing the One Faith, of the World Council of Churches, articulates this threefold understanding of faith. Faith is to believe that God exists (credere Deum). Faith is to believe God (credere Deo). Faith is, thirdly, to believe in God (credere in Deum). Faith, therefore, implies a rational acceptance of God's existence, seriousness about God's Word, and trust, submission, dedication, commitment and obedience to Him.

A distinction should also be made between the act of believing (fides qua) and the content of our belief (fides quae). Blessed assurance is not to be found in our act of believing, but rather in the content of our faith, in the one in whom we believe and trust. We do not reside in the fact that we believe, but in the triune God, in whom we believe. We are, therefore, not always sure whether we believe, and whether we believe good enough, but we are always sure in whom we believe. Bonhoeffer $(1995,99)$ describes this distinction between faith as fides qua and faith as fides quae in a remarkable way:

A life is not justified by love or by hope, but only by faith. For indeed faith alone sets life upon a new foundation, and it is this new foundation alone that justifies my being able to live before God. This foundation is the life, the death and the resurrection of the Lord Jesus Christ. ... And faith means the finding and holding fast of this foundation. It means casting anchor upon it and being held fast by it. ... Faith is a passive submission to an action, and in this submission alone it is itself an action.... But faith is never alone. ... It would be a false faith, a dissembling faith, a hypocritical and self-invented faith such as can never justify, if it were not accompanied by love and hope.

Faith, as a virtue, guides our leadership and decision-making. To lead and decide with faith, is to know we have God as our anchor; is to be assured that we are not alone; is to be driven by proven principles and values; is to be guided by examples and role-models; is to ask what would Jesus do; is to be enabled and empowered by Jesus; is to dare to decide with assurance and calmness amidst uncertainty and risk.

\section{Virtuous Leadership and Decision-making in Hope}

Over decades, German theologian, Jürgen Moltmann, has helped us to understand Christian hope. Moltmann (1996, xv-xvi) describes hope as hope in God for the resurrection and eternal life of human people; the renewal of the human and non-human world; and the joyous actualisation and fulfilment of God's glory. For him, hope is personal and cosmic hope. Eschatology is individual and universal eschatology. The centre of hope is God, God's glory and God's kingdom. 
Hope, according to American theologians, Hauerwas and Pinches $(1997,175)$ is not tempered optimism.

... there is a kind of tempered optimism in which people "either rest too confidently on their past experiences of overcoming dejection or manifest a phlegmatic or unreflected disposition at inappropriate times. Their optimism, then, reflects a flawed hope that is close to dullness or presumption. It displays an intemperate attitude that expresses itself in the naïve belief that all will turn out for the best." Christians have no such wane hope, sustained as we are by a patience that looks to our misfortunes, even the misfortune of our illness and death, as part of our service to one another as God's people.

Hope impacts upon our leadership and decision-making. Realistic hope, that is not an illusion or daydreaming, but hope that knows our God is real and alive and present, and victoriously engaged with us. Resilient, elastic hope that knows circumstances can test and stretch us, but it will never break us. It is responsive hope that is not a withdrawal from the world, but that gets involved in the world - energetically and pro-actively, imaginatively and innovatively, practically and positively.

\section{Virtuous Leadership and Decision-making in Love}

For Augustine and Thomas, caritas, or love, is the essence of the virtues. For Augustine love is seen in the forms of the four cardinal virtues, which all seek to honour God and to serve God's. Temperance and moderation are a form of love that represents full surrendering to God. Courage or fortitude is love that tolerates everything with joy for the honour of God and the wellbeing of God's. Justice is love that pays the highest loyalty and service to God alone and, therefore, seeks fairness for all. Wisdom is love that discerns the things in all facets of life that strengthens our relationship with God and God's. All virtue and morality rest on love. Our mores are informed by amores (cf. Koopman and Vosloo 2002, 69-70). Thomas describes charity as the mother of all virtue, which has the nurturing function to animate all successive acts of virtue (cf. Keenan 2002, 84).

Bonhoeffer $(1995,35)$ argues that we learn about love in the person of Jesus Christ. The emphasis should not be on the loving acts of Christ, but on his loving being. "Love is not what He does and what He suffers, but it is what He does and what He suffers. Love is always He Himself. Love is always God Self. Love is always the revelation of God in Jesus Christ."

According to Bonhoeffer $(1995,36)$, there is not a distinction between the love of Christ and the love of Christians. There is only one love, namely the love of God in Christ. The love of humans is nothing other than the love of Christ. With regard to love, humans are always passive.

And so, love is something which happens to man [sic], something passive, something over which he [sic] does not himself [sic] dispose, simply because it lies beyond his existence in disunion. Love means the undergoing of the transformation of one's entire 
existence by God; it means being drawn in into the world as it lives and must live before God and in God. Love, therefore, is not man's [sic] choice, but it is the election of man [sic] by God. (Bonhoeffer 1995, 35)

Bonhoeffer $(1995,37)$, however, cautions that this passivity should not be understood as inactivity.

Being loved by God does not by any means deprive man [sic] of his mighty thoughts and his spirited deeds. It is as whole men [sic], as men [sic] who think and who act, that we are loved by God and reconciled with God in Christ. And it is as whole men [sic], who think and who act, that we love God and our brothers [sic].

Love guides our leadership and decision-making. Love is to pay attention; it is to use all our senses and sensibilities to identify and consider everyone's desires, longings, dreams, ideals, quests, needs, concerns, cares and interests. Love is to seek the wellbeing and thriving, flourishing and blossoming of everyone, especially of the most vulnerable.

\section{Virtuous Leadership and Decision-making in Wisdom}

People with wisdom and discernment are capable of distinguishing between right and wrong, good and bad, holy and unholy, faithfulness to God and unfaithfulness, obedience to God's will and disobedience. In a modern-postmodern, glocalised (global and local impact on each other) world, where choice options are plentiful, people need wisdom and discernment.

Moreover, in a tragic world where there are many aporias, dead-end streets, the need for wise and prudent people is even bigger. In such an aporetic ${ }^{3}$ world the choice is not always between right and wrong, but between more wrong and less wrong, and between more right, and less right. Discernment entails that we sometimes have to choose for the lesser of two or more evils and to do it not with concession, but with confession of guilt and hope. We make these choices, knowing that we did not meet the ideal, and that we did not have a concession to do it. We know that, even though the choice was unpreventable, and though it is the least of all evil possibilities, it remains evil. Therefore, we make this type of choices with confession of guilt and pain, and also with the confession of hope for forgiveness and new beginnings.

Wisdom also means we have to be able to prioritise, to discern what and who require attention and priority now at this specific point in time.

Bonhoeffer (1995, 50-51) also emphasises the importance of discerning the things that really matter, to perceive the essential nature of things, to see into the depth of things, to see reality as it is. To achieve this, the multiplicity of knowledge of the world is

3 For a description of the aporetic nature of existence, see Zygmunt Bauman, Postmodern Ethics, 1993, 8 . 
helpful, but not essential. In fact, the best informed person is not necessarily the wisest. Although knowledge of trivial detail sometimes might help to see into the depth of things, we are not dependent upon it. To achieve this wisdom that sees into the depth of things, we need simplicity.

To be simple is to fix one's eye solely on the simple truth of God at a time when all concepts are being confused, distorted and turned upside-down. It is to be singlehearted, and not a man [sic] of two souls ... (Jas. 1.8). Because the simple man [sic] knows God, because God is his [sic], he [sic] clings to the commandments, judgements and the mercies which come from God's mouth every day afresh. Not fettered by principles, but bound by love for God, he [sic] has been set free from the problems and conflicts of ethical decision. They no longer oppress him [sic]. He [sic] belongs simply and solely to God and to the will of God. It is precisely because he [sic] looks only to God, without any sidelong glance at the world, that he [sic] is able to look at the reality of the world freely and without prejudice. And that is how simplicity becomes wisdom. (Bonhoeffer 1995, 50)

Wisdom is indispensable for leadership and decision-making. Wisdom is to discern, judge, sense what is at the heart of the matter; what should enjoy priority; what is more right and what is less right; what is more wrong and what is less wrong; what is onesidedly wrong and what is one-sidedly right; what should be done now and what later; what are the relevant information, data, facts; what are the relevant guiding directives; what are the motivations that drive us; what are potential consequences of our choices; what is the implication of the type of persons, institutions and societies we want to be for our choices, i.e. what is the relationship between our individual character and our individual choices, between our institutional character and our institutional choices, between our character as society and our societal choices.

\section{Virtuous Leadership and Decision-making in Moderation}

Temperance, from the Latin temperantia, literally means the right measure, or the right order. Temperance is, therefore, a virtue that indicates that you guard against the excessive use of goods. Simultaneously it implies guarding against the insufficient use of goods. This quest for the right measure or order does not only have to do with material or bodily goods. In fact, in all facets of life the temperate person strives for the right order or measure. ${ }^{4}$

With an appeal to Thomas Aquinas, Dutch ethicist, Paul van Tongeren (2003, 109-111) refers to the different dimensions of temperance. Shame (Verecundia) is the fear for a shameful act; honesty (honestas) is the appropriate and not lustful enjoyment of goods; abstinence (abstinentia) is the joyful quest for the right measure, for the sake of the good life and the kingdom of God. Van Tongeren $(2003,109)$ phrases it as follows: "Wie niet

4 The Afrikaans word for temperance, matigheid, can be rendered as maat-tigheid to express that we seek for the right measure (maat) in everything. 
lachend het goede doet, die is op zijn best een beginner. Ook als milieuactivist moet je soms in de spiegel kijken." Sobriety (sobrietas), according to Van Tongeren, is for Thomas Aquinas the quest to find the right measure regarding the use of wine. Chastity (castitas) is the rational quest for the right measure regarding sexual desire; and directly related to this, virginity (virginitas) is the quest for the right measure in sexual matters for the sake of the good life. Anger and protest activities are to be accompanied by mildness (clementia) and tenderness or meekness (mansuetudo). Modesty (modestia), willingness to learn (studiositas) and humility (humilitas) are dimensions of temperance which oppose pride (superbia and hybris).

Virtuous living for Christians is the quest for this right measure in all relationships and in all facets of life, in the light of God's Word and the other sources of morality of the Christian tradition.

Moderation guides our leadership and decision-making. Moderation is to guard against arrogant extremes, and to humbly see the nuances and finer details. It is, therefore, to be cautious of populist positions that either absolutise or totally relativise. It is to explore the value of the so-called Golden Mean, which means I have a strong position on a matter, but it is not a position that is built on extremes and that is not open for reconsidering. Moderation is to consistently look for the right measure-God's measure. It is to guard against greed and gluttony in everything. It is to avoid exaggeration. It is to give the right weight to motivations, interests, longings, ideals, emotions, arguments, consequences in decision-making. It is to practise temperance, discipline, self-regulation and self-control, because we are controlled by the Spirit.

\section{Virtuous Leadership and Decision-making in Fortitude}

Stanley Hauerwas and Charles Pinches (1997, 149-165) offer helpful views on courage. They analyse the views of Aristotle and Aquinas on courage. Courage, according to Aristotle, is to conquer fear, especially the fear of noble death. For Aristotle, death in battle is a noble death. To have courage is to be willing to die in battle. Hauerwas and Pinches appreciate Aquinas's idea that the noble death that we should not fear is the death of martyrdom and persecution. Based on this, they argue that death in battle suggests that we use the same means as our enemies. This life-destructive orientation does not bring hope to the world. But those who die in martyrdom do not use lifedestructive means. They have the confidence that God will complete the work that $\mathrm{He}$ has begun in them, even if their lives are taken by their enemies. Moreover, they have not merely the victory of the nation and the common good as telos, but the friendship of all with God, of which a life of dignity is an important ingredient. The extraordinary death through persecution also shows how martyrs are committed to a life of sacrifice 
throughout their lives, in all daily acts and practices, for the sake of friendship of all with God.

Courage is demonstrated in extraordinary circumstances, like in opposition to Nazism and apartheid. But it is also, perhaps even mostly, required in the so-called ordinary events and challenges of every day, like paying attention to the plights of family members and friends and those outside this circle. It is necessary when a moral "no" is required, even though everyone else is saying "yes." These courageous people, moral heroes, are called for, not only when extraordinary challenges are faced, but also when we deal with the seemingly ordinary challenges of daily life.

The explanation of courage up to now makes it clear that courage does entail concrete and active engagement, but also endurance. In this sense, courage is related to patience. Hauerwas and Pinches (1997, 175-176) reckon patience is the most neglected virtue in modern societies where the levels of addiction to hyperactivity is very high. Where people are aware of the presence and involvement of God in the world, they oppose the impatience of Eve and Adam which made them break God's commandment, and the impatience of Cain which made him become the killer, instead of the shepherd of his brother, and the impatience which makes us desert our suffering brothers and sisters because we impatiently reckon that if we cannot immediately cure, we can also not patiently care.

Fortitude guides our leadership and decision-making. We need fortitude to make difficult decisions, and to implement them, and to take responsibility for them. We need the courage to act where we should, and the courage to be patient and wait where we should. We need the courage to say no where we should, even when all others say yes, and to say yes where we should, even when all others say no. We need fortitude to bear and endure the hardships of life, also the hardship that decision-making often implies. Give us the strength to be humbly brave amidst threat. Give us the strength amidst vulnerability, to persevere and to perish never. Give us the fortitude that overcomes all fear.

\section{Virtuous Leadership and Decision-making in Justice}

Just persons do not only adhere objectively to justice as a moral value that guides private and public life. For them, justice is an embodied, incarnated value that almost intuitively guides their way of being, living, deciding and acting in this world.

The various descriptions of justice that societies strive to adhere to, are embodied by virtuous individuals. Utilitarian theories of justice envisage a just society as one where that which is of utility to the highest number of people, is achieved. Communitarian theories of justice reckon that solidarity opens the doors to justice. Egalitarian theories plead for equal access to the most basic goods for all people. Libertarian theories stress 
the freedom of especially individuals to develop potentialities as the way towards justice. $^{6}$

After an analysis of various theories of justice, including the emphasis of Liberation Theology on the priority of the poor and vulnerable in the justice discourse, and the quest of the famous 1986 letter of the American Catholics Bishops on the economy, which amongst others pleads for equal distribution of goods especially to the poor, Karen Lebacqz (1987) pleads that the narrative of the poor and vulnerable be attended to in higher measure, and that it receives epistemological preference in justice discourses.

Elsewhere, I (2009) plead, with amongst others an appeal to the meaning of the Hebrew words for justice, mishpat and tsedaqah, for an understanding of justice as compassionate justice and restorative justice, which entails both forensic, or juridic, and sacrificial justice. This understanding of justice includes, but is more than retributive, distributive and rehabilitative justice.

We need the virtue of justice as both the lodestar and outcome of our leadership, and of our decision-making and policy-making processes. Justice takes shape where everyone experiences dignity; where everyone experiences the fulfilment of human rights; where everyone experiences restitution, restoration, reparation, healing of various wounds; where everyone experiences freedom from repression and exploitation and alienation; where everyone experiences that we really are of equal worth and value and esteem; where everyone lives in a society of equity (aequitas), equilibrium, ewewig, a society where some don't have too much and others too little.

\section{Conclusion}

The virtues are interdependent. All of them are geared toward justice for all. Justice is the outcome of virtuous living. Justice is the supreme virtue. Justice is the supreme good, the Summum Bonum. Without justice, the other virtues become vices.

Plaatjies-Van Huffel sought justice throughout her life. ${ }^{7}$ As a black, or coloured person who experienced racial injustice, her quest was for justice. As a woman in a patriarchal and misogynist society, her quest was for justice. As a person who knew about socioeconomic disadvantage, her quest was for justice for all, especially for the destitute, the poor and the wronged. As a heterosexual female in a society of heterosexism and homophobia, her quest was for justice. As an African in a world of Afro-pessimism, her

6 For a helpful analysis of these theories of justice, see Beauchamp, T. L., and J. F. Childress 2001. Principles of Biomedical Ethics.

7 One of the last publications of Plaatjies-Van Huffel (2019) offers a narrative of her struggle for gender justice in the Uniting Reformed Church in Southern Africa. Future engagement with that article from the perspective of virtue ethics is a worthwhile endeavour that could contribute to the continuous reception and celebration of Plaatjies-Van Huffel. 
quest was for justice. As a human being in a world of anthropocentrism and specie-ism, she hungered for justice. Yes, her quest was for justice everywhere and for everyone. She knew an injury to justice anywhere is an injury to justice everywhere.

In seeking justice in church and in the world, she was nurtured by the contents of her faith, the Triune God and those who belong to God, including her husband, parents, sisters, family, friends and colleagues, congregants and comrades in all walks of life. Her justice quests were mobilised by realistic, resilient and responsive hope. Her resolute refusal to be despaired will always stay with us. Love was the motor of her work for justice. She cared about people. She paid attention. She showed interest. And she always attempted to give her best. She embodied the excellence of love. PlaatjiesVan Huffel's justice quests were informed by wisdom, sensitive intuition, sound judgement, careful discernment. Her wisdom (sapientia) grew from her scientific knowledge (scientia). Her bibliography reflects her hard scientific labour. She consistently engaged with scholars from a variety of disciplines in building her academic trajectory, and in nurturing wisdom and discernment. She also sought justice through moderation and temperance. She guarded against extreme, absolutist and populist positions. She attended to all positions, and advanced justice in an equitable, fair and level-headed manner. She also took the courage to make an unfamous decision and to implement it. With the fortitude of patience, and with the fortitude of courageous action, she made and implemented decisions.

The international mourning, from the most global to the most local circles, at the time of her death, showed how this pastor, professor, international ecumenical servant of virtuous leadership and decision-making could advance justice, and could succeed to bring people of different and contradictory positions together in the joint cause of justice for all, especially for the most marginalised. Plaatjies-Van Huffel demonstrated that seeking the virtue and life of justice in a virtuous manner, does not alienate people, but wins them over for the cause of kingdom life of justice, which culminates in everlasting peace and joy (Isaiah 32; 65:17-25; Romans 14:17)! Our last conversation shortly before she passed on, took place telephonically while she was in the hospital. I could not see, but I could clearly hear her smile; that peaceable smile of faith, hope, love, wisdom, moderation, fortitude and justice, which the world could not change.

\section{References}

Barnes, K. J. 2018. Redeeming Capitalism. Grand Rapids, Michigan: William B. Eerdmans.

Bauman, Z. 1993. Postmodern Ethics. Oxford: Blackwell.

Beauchamp, T. L. and J. F. Childress. 2001. Principles of Biomedical Ethics, 5th edition. New York: Oxford University Press.

Birch, B., and L. Rasmussen. 1989. Bible and Ethics in the Christian Life. Minneapolis: Augsburg Press. 
Bonhoeffer, D. 1995. Ethics. London: SCM Press.

Childs, J. 1992. Faith, Formation and Decision. Ethics in the Community of Promise. Minneapolis: Fortress Press.

Confessing the One Faith. An Ecumenical Explication of the Apostolic Faith as it Is Confessed in the Nicene-Constantinopolitan Creed (381). Geneva: World Council of Churches Publications.

Cunningham, D. S. 1998. These Three Are One. The Practice of Trinitarian Theology. Oxford: Blackwell Publishers.

Hauerwas, S., and C. Pinches. 1997. Christians among the Virtues. Theological Conversations with Ancient and Modern Ethics. Notre Dame: University of Notre Dame Press.

Hursthouse, R. 2000. On Virtue Ethics. Oxford: Oxford University Press.

Keenan, S. J. 2002. "Moral Theological Reflections.” In Jesus and the Virtues. Building Bridges between New Testament Studies and Moral Theology, edited by D. Harrington and J. Keenan. Chicago: Sheed and Ward, 82-90.

Koopman, N. 2005. “This Is who he Is! Beyers Naudé: A Man of Virtue and Character.” In The Legacy of Beyers Naudé. Beyers Naudé Centre Series on Public Theology, edited by L. Hansen. Stellenbosch: Sun Press, 153-168.

Koopman, N. 2007. "Towards a Human Rights Culture in South Africa. The Role of Moral Formation." NGTT 48: 107-118.

Koopman, N. 2009. “Justice and Land Reform.” In The God-given Land. Religious Perspectives on Land Reform in South Africa, edited by E. van der Borght. Amsterdam: Rozenberg Publishers, 95-104.

Koopman, N. 2012. "The Common Good and Human Dignity: Some very Preliminary Remarks." NGTT: Ned Geref Teologiese Tydskrif 53 (Supplementum 2): 31-40. https://doi.org/10.5952/53-0-212.

Koopman, N., and R. Vosloo. 2002. Die Ligtheid van die Lig. Morele Oriëntasie in 'n Postmoderne Tyd. Wellington: Lux Verbi.

Lebacqz, K. 1987. Six Theories of Justice. Perspectives from Philosophical and Theological Ethics. Minneapolis: Augsburg Publishing House.

Moltmann, J. 1996. The Coming of God. Christian Eschatology. London: SCM Press.

Plaatjies-Van Huffel, Mary-Anne E. 2019. "A History of Gender-insensitivity in URCSA.” Studia Historiae Ecclesiasticae 45 (3): 1-22. 
Rothuizen, G. 1973. Wat is Ethiek? Kampen: Kok.

Van Tongeren, P. 2003. Deugdelijk Leven. Een Inleiding in de Deugdethiek. Amsterdam: Uigeverij Sun.

Wogaman, J. P. 1989. Christian Moral Judgment. Louisville: Westminster/John Knox Press. 